\title{
Biochemical quality of cowpea beans grown under water-deficit maintained with hydrogel
}

\author{
La calidad bioquímica de los frijoles de caupí cultivados \\ bajo déficit hídrico se mantiene con hidrogel
}

\begin{abstract}
Rodrigo Ribeiro Fidelis"; Guilherme Sousa da Silva ${ }^{2}$; Wagner Augusto Rauber ${ }^{3}$; Larissa Urzêdo Rodrigues ${ }^{4}$; Vitor L. Nascimento ${ }^{5}$; Susana Cristine Siebeneichler ${ }^{6}$
\end{abstract}

\begin{abstract}
$\frac{\text { ARTICLE DATA }}{1 \text { Research professor, Ph.D. Universidade Federal do }}$ Tocantins, Tocantins, Brasil, fidelisrr@uft.edu.br.

2 Research, Agricultural Engineer, Universidade Federal do Tocantins, Tocantins, Brasil, guilheermess@gmail.com.

Research, Agricultural Engineer, Universidade Federal do Tocantins, Tocantins, Brasil, wrauber@ hotmail.com.

4 Research, Ph.D. Universidade Federal do Tocantins, Tocantins, Brasil, larissaurzedo@hotmail.com.

5 Research, Ph.D. Universidade Federal do Tocantins, Tocantins, Brasil, vitorlnasc@gmail.com.

6 Professor, Ph.D. Universidade Federal do Tocantins, Tocantins, Brasil, susana@uft.edu.br.
\end{abstract}

Cite: Fidelis, R.R.; da Silva, G.S.; Rauber, W.A.; Rodrigues, L.U.; Nascimento, V.L.; Siebeneichler, S.C. (2020). Biochemical response of cowpea beans grown under water-deficit and hydrogel. Revista de Ciencias Agrícolas. 37(2): 38 - 50.

doi: https://doi.org/10.22267/rcia.203701.123

Received: February 032020.

Accepted: May 022020.

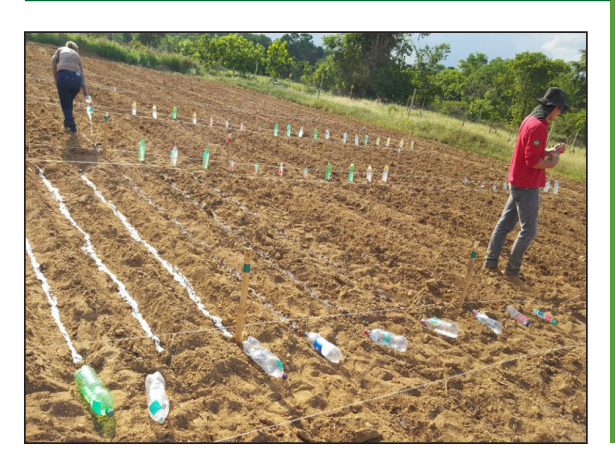

\section{ABSTRACT}

Investigations related to the effects of the hydrogel use in a water-deficit conditions on the biochemical composition of the harvested products are scarce. The aim of this study was to verify the influence of hydrogel on the biochemical response of cowpea beans produced under water-deficit in southern Tocantins. The experiment was a randomized complete block design with four replications. The treatments were obtained in a $2 \times 5$ factorial scheme, being: two sources of hydrogel (Hydroplan-EB HyC and Polim-Agri PP) and five concentrations (0, 5, 10, 15, and 20kg ha-1). After harvesting, the grains of cowpea, BRS Vinagre cultivar, were ground and chemically analyzed. The oil content of the seeds agreed with the reference values. The use of Polim-Agri PP promoted the best levels of amino acids $\left(0.38 \mathrm{mg} \mathrm{g}^{-1}\right)$ and proteins $\left(243.22 \mathrm{mg} \mathrm{g}^{-1}\right)$ of the grains. The carbohydrate content of them ( $\left.\bar{Y}=81.44 \mathrm{mg} \mathrm{g}^{-1}\right)$ was better using Hydroplan-EB HyC, regardless of the concentration applied. The application of $6.28 \mathrm{~kg} \mathrm{ha}^{-1}$ of Polim-Agri PP provided the highest starch content $\left(842 \mathrm{~g} \mathrm{mg}^{-1}\right)$. The use of hydrogel improves the biochemical quality of cowpea beans produced under water deficit in southern Tocantins.

Keywords: grain composition; soil-conditioning polymer; water-deficit; Vigna unguiculata (L.).

\section{RESUMEN}

Son pocas las investigaciones relacionadas con los efectos del uso del hidrogel en condiciones de déficit hídrico en la composición bioquímica de los productos cosechados. El objetivo de este estudio fue verificar la influencia del hidrogel en la calidad bioquímica del frijol caupi producidos bajo el déficit hídrico en el sur de Tocantins. El experimento se realizó en bloques aleatorios con cuatro repeticiones. Los tratamientos se obtuvieron en un esquema factorial 2x5, siendo: dos fuentes de hidrogel (HydroplanEB HyC y Polim-Agri PP) y cinco concentraciones (0, 5, 10, 15 y $20 \mathrm{~kg}$ 
$h^{-1}$ ). Después de la cosecha, los granos del frijol caupi, cultivados con vinagre BRS, fueron molidos y analizados químicamente. El contenido de aceite de las semillas está de acuerdo con los valores de referencia. El uso del Polim-Agri PP promovió los mejores niveles de aminoácidos $\left(0,38 \mathrm{mg} \mathrm{g}^{-1}\right)$ y proteínas $\left(243,22 \mathrm{mg} \mathrm{g}^{-1}\right)$ de los granos. El contenido de carbohidratos $\left(\bar{Y}=81,44 \mathrm{mg} \mathrm{g}^{-1}\right)$ fue mejor con Hydroplan-EB HyC, independientemente de la concentración aplicada. La aplicación de 6,28 $\mathrm{kg} \mathrm{ha}^{-1}$ de Polim-Agri PP proporcionó el mayor contenido de almidón (842 $\mathrm{g} \mathrm{mg}^{-1}$ ). El uso de hidrogel mejora la calidad bioquímica del frijol caupi producida bajo déficit hídrico en el sur de Tocantins.

Palabras clave: Composición de los granos; déficit hídrico; polímero acondicionador del suelo; Vigna unguiculata (L.).

\section{INTRODUCTION}

In the Cerrado region, producers have increased their interest in cowpea crop (Vigna unguiculata (L.) Walp.), mainly in the second crop season, attracted by the very competitive cost (Melo et al.,2018) and supported by the recommendation of promising genotypes regarding grain yield and the possibility of adaptation to the farming systems (Sousa et al., 2017; Silva et al., 2017). However, the occurrence of climatic adversities has hampered the production and supply of high-quality products, endangering the opening of new markets for this crop (CONAB, 2019).

Although this legume is relatively tolerant to water deficit (Dutra et al., 2015), the reduction in the availability of water in the soil due to periods of drought and high temperatures impairs the plant metabolism, causing morphophysiological and biochemical modifications that affect its growth and development (Taiz and Zeiger, 2013; Boughalleb et al., 2016), especially if stress occurs at the reproductive stage of the crop (Murga-Orrillo et al., 2016).

Current climate projections indicate an increase in the incidence and severity of drought, which makes fundamental the search for new strategies to optimize the water use efficiency in agriculture (Dehkordi, 2016). In this sense, the hydrogels as soil conditioners has contributed to improve the storage of water and release under drought conditions, particularly in areas with limited water supply and restricted nutrient conditions (Ullah et al., 2015).
Hydrogels are networks of biodegradable threedimensional polymers that retain water in their structure, forming a gel capable of hydrating and releasing water for a long period (Sartore et al., 2013; Guilherme et al., 2015). In plants, the benefits of its use reflect on the morphology and productivity, being generally associated with the increase in the efficiency of fertilizer use (Khalaki et al., 2019; Scremin et al., 2017; Mamann et al., 2017; Fidelis et al., 2018; Lopes et al., 2018; Pereira et al., 2018).

On the other hand, although the biochemical composition of products harvested from plants exposed to water stress conditions is well reported (Singh et al., 2008, Beltrano et al., 2006; He et al., 2012), the influence of hydrogel use on these traits are scarce (Moghadam et al., 2011), especially for cowpea beans, one of the main sources of vegetable protein in the world (Freitas et al., 2017). The aim of this study was to evaluate the influence of sources and concentration of hydrogel on the biochemical response of cowpea beans grown under water deficit in southern Tocantins.

\section{MATERIAL AND METHODS}

Condition of crop in field. The work was carried out in the field of Experimental Station of Universidade Federal do Tocantins (UFT)

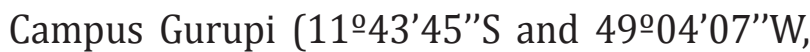
at 280 masl), in the crop season of 2015/2016, on a Dystrophic Red-Yellow Latosol (Santos et al., 2013). 
Soil samples were collected from the $0-20 \mathrm{~cm}$ layer for chemical and physical analysis. The results indicated: $\mathrm{pH}$ in $\mathrm{CaCl} 2=5.3 ; \mathrm{OM}(\%)=$ 1.7; $\mathrm{P}($ Mehlich $)=10.4 \mathrm{mg} \mathrm{dm}^{-3} ; \mathrm{K}=71 \mathrm{mg} \mathrm{dm}^{-3}$; $\mathrm{Ca}+\mathrm{Mg}=2.8 \mathrm{cmolc} \mathrm{dm}^{-3} ; \mathrm{H}+\mathrm{Al}=2.2 \mathrm{cmolc} \mathrm{dm}^{-3}$ ; $\mathrm{Al}=0.0 \mathrm{cmolc} \mathrm{dm}-3$; $\mathrm{SB}=2.98 \mathrm{cmolc} \mathrm{dm}^{-3} ; \mathrm{V}=$ $58 \% ; 715 \mathrm{~g} \mathrm{~kg}^{-1}$ of sand; $50 \mathrm{~g} \mathrm{~kg}^{-1}$ of silt and $235 \mathrm{~g}$ $\mathrm{kg}^{-1}$ of clay. The crop was fertilized with $300 \mathrm{~kg}$ ha $^{-1}$ of Super-simple $\left(20 \% \mathrm{P}_{2} \mathrm{O}_{5}\right)$ and $34 \mathrm{~kg} \mathrm{ha}^{-1}$ of Potassium Chloride $\left(60 \% \mathrm{~K}_{2} \mathrm{O}\right)$.

The climate of the region is mesothermic, with summer rains and dry winter (Alvares et al., 2013). The meteorological data regarding the period of conduction of the experiment are displayed in Figure 1.

The experiment was conducted in a randomized complete block design with four replications. Ten treatments were obtained from $2 \times 5$ factorial scheme, being: two sources of hydrogel (Hydroplan-EB HyC and Polim-Agri PP) and five concentrations $\left(0,5,10,15\right.$, and $\left.20 \mathrm{~kg} \mathrm{ha}^{-1}\right)$.
The treatments were applied in the crop rows

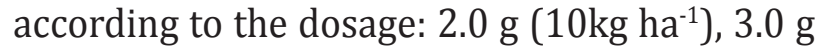

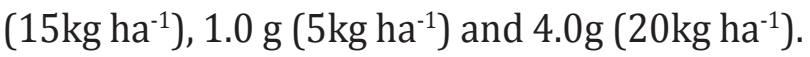
The cowpea seeds cultivar BRS Vinagre were treated with a commercial product, following the recommendations for the culture (EMBRAPA, 2002). Field sowing consisted of experimental plots with four $4.0 \mathrm{~m}$ long rows spaced $0.5 \mathrm{~m}$. During the production cycle the cultural practices were carried out according to the crop needs. For the grain harvest ( 80 days after sowing), the useful area used corresponded to the two central rows, $0.50 \mathrm{~m}$ from the ends of each line and eliminating the two lateral lines, totaling $3.0 \mathrm{~m}^{2}$.

Biochemical analysis. In order to evaluate the biochemical response of the harvested cowpea beans, they were sent to the laboratory analysis, where they were first ground in a Willey type mill (STAR FT 50 model) and stored in a desiccator. Subsequently, the samples followed for biochemical analysis.

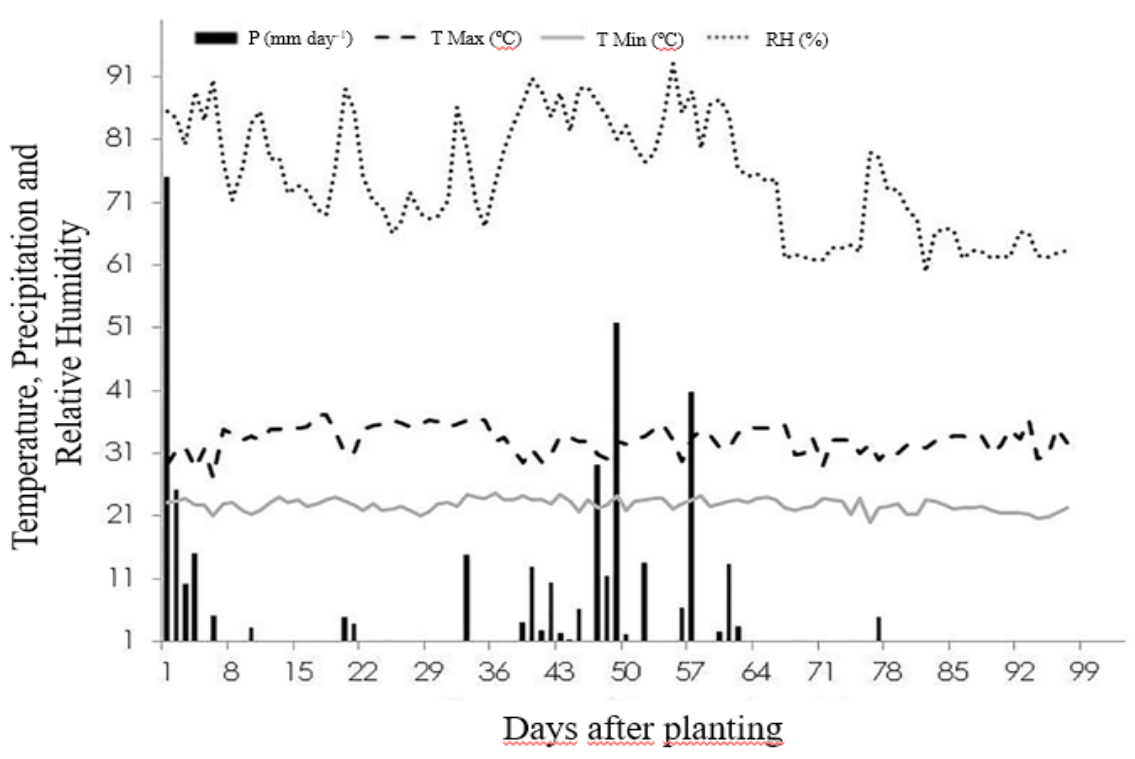

Figure 1. Maximum and minimum temperatures $\left({ }^{\circ} \mathrm{C}\right)$, pluvial precipitation $(\mathrm{mm})$, and relative air humidity (\%), occurred during crop season 2015/, 2016 (INMET, 2016). 
Oil content (\%). The methodology proposed by Castro (2016), using pure hexane for extraction was carried out. The samples were centrifuged and the supernatant discarded. The precipitate was dried in an oven at $50^{\circ} \mathrm{C}$, until constant weight (about $24 \mathrm{~h}$ ). The results were determined by difference in weight of the sample before and after this procedure.

After quantifying the oil content, the defatted precipitate became the basis for further quantifications performed using the ethanol extractor $(\mathrm{EtOH})$. Thus, the samples were centrifuged and the collected supernatants were stored in a freezer until the time of analysis. The precipitates were oven dried for further evaluation. From the supernatant of the ethanolic extraction were quantified amino acids, carbohydrates, starch and proteins.

Total soluble amino acid content ( $\left.\mathrm{mg} \mathrm{g}^{-1}\right)$. The methodology proposed by Peoples et al. (1989) with replacement of the ninhydrin reagent by alcoholic ninhydrin (70\%), according to Friedman and Brandon (2001). For this, aliquots of the supernatant were placed in hermetically sealed test tubes and incubated in a water bath. The reaction was interrupted cold (ice bath) and, subsequently, readings of the absorbance in digital spectrophotometer (edutec and model EEQ-9023) at $570 \mathrm{~nm}$. The curve was performed using the amino acid tryptophan.

Total soluble carbohydrate content $\left(\mathrm{mg} \mathrm{g}^{-1}\right)$ was measured according to the methodology proposed by Dubois et al. (1956). In this analysis, an aliquot of the supernatant was used, distilled $\mathrm{H}_{2} \mathrm{O}$ and concentrated $\mathrm{H}_{2} \mathrm{SO}_{4}$ were added, followed by vortexing. After resting, absorbance readings were taken on a digital spectrophotometer (edutec brand and model EEQ-9023) at $490 \mathrm{~nm}$. The curve was performed using glucose.
Starch content ( $\mathrm{mg} \mathrm{g}^{-1}$ ). The methodology proposed by Dubois et al. (1956) with adaptation of MacRae et al. (1974) replacement of perchloric acid by sulfuric acid, due to the availability. For the extraction of starch, a volume of $\mathrm{H}_{2} \mathrm{SO}_{4}$ was added to the mass of the precipitate in all of the test, proceeding with centrifugation. The supernatant was collected and stored. After homogenization with phenol, an aliquot of concentrated $\mathrm{H}_{2} \mathrm{SO}_{4}$ was added again, followed by vortexing. After rest, absorbance readings were taken on a digital spectrophotometer (edutec brand and model EEQ-9023) at $490 \mathrm{~nm}$. The curve was performed using glucose.

Total soluble protein content ( $\left.\mathrm{mg} \mathrm{g}^{-1}\right)$. the methodology used was that of Bradford (1976), adding an aliquot of $\mathrm{KOH}$ for homogenization to the alcoholic extraction precipitate, followed by incubation in a water bath. To quantify the levels of total soluble proteins, an aliquot of the Bradford reagent (Bio-RadLaboratories, Inc.) was added, followed by vortexing and rest. The absorbance readings were performed on a digital spectrophotometer (edutec brand and model EEQ-9023) at $595 \mathrm{~nm}$. The curve was performed using Bovine Serum Albumin (BSA).

\section{Statistical analysis}

Two-way Analysis of Variance (ANOVA) and, when significant by the $\mathrm{F}$ test, the Tukey multiple pairwise-comparison were carried out to detect differences between treatments, using the statistical software SISVAR version 5.6 (Ferreira, 2011). The graphs were plotted using SigmaPlot ${ }^{\circledR}$ software version 10.0 (SSI, 2006).

\section{RESULTS AND DISCUSSION}

The summary of the analysis of variance for the biochemical quality of the cowpea beans is presented in Table 1. The oil contents, total soluble carbohydrates and starch of the grains 
were influenced by the significant interaction ( $p \leq 0.05$ ) between the sources and hydrogel concentrations applied. On the other hand, there was an isolated effect for sources and concentrations of hydrogel on total soluble amino acids and total soluble protein content of the grains.

The oil content of the cowpea beans varied in a quadratic manner positive for both sources of hydrogel used as a function of the applied concentrations (Figure 2). Although the maximum response occurred in the absence of hydrogel $-0.0 \mathrm{~kg} \mathrm{ha}^{-1}(\overline{\mathrm{Y}}=3.35 \%$ oil $)$, the use of Polim-Agri PP and Hydroplan-EB HyC sources at a concentration of $20 \mathrm{~kg} \mathrm{ha}^{-1}$ recovered the oil content of the grains, respectively, 0.43 and $0.70 \%$, compared to the lowest accumulation observed at the estimated mean concentration of $12.72 \mathrm{~kg} \mathrm{ha}^{-1}$.

Table 1. Analysis of variance of the traits oil content, total soluble amino acids (TSA), total soluble carbohydrates (TSC), total soluble proteins (TSP) and starch in cowpea beans under the influence of sources $(\mathrm{S})$ and concentrations $(\mathrm{C})$ of hydrogel in the 2015/2016 crop season in Gurupi-T0.

\begin{tabular}{ccccccc}
\hline SV & DF & Oil & TSA & TSC & TSP & Starch \\
\hline Sources & 1 & $0.015^{\text {ns }}$ & $0.007^{* *}$ & $3,046.26^{* *}$ & $1,188.30^{*}$ & $1,962.48^{\text {ns }}$ \\
Concentrations & 4 & $3.821^{* *}$ & $0.002^{\text {ns }}$ & $887.20^{* *}$ & $1,547.39^{* *}$ & $3,5142.71^{*}$ \\
S x C & 4 & $4.091^{* *}$ & $0.001^{\text {ns }}$ & $991.30^{* *}$ & $518.14^{\text {ns }}$ & $118,341.73^{* *}$ \\
Blocks & 3 & $0.025^{\text {ns }}$ & $0.0004^{\text {ns }}$ & $470.12^{\text {ns }}$ & $16.88^{\text {ns }}$ & $21,403.40^{\text {ns }}$ \\
Residuals & 27 & 0.125 & 0.0001 & 172.71 & 228.04 & $10,853.17$ \\
\hline CV (\%) & & 16.06 & 7.55 & 18.07 & 6.35 & 15.45 \\
Average & & 2.199 & 0.367 & 72.716 & 237.77 & 674.17 \\
\hline
\end{tabular}

SV: source of variation; DF: degrees of freedom; CV: coeficient of variation; ${ }^{\text {ns }}$ not significant, ${ }^{*}$ significant at $5 \%$ and ${ }^{* *} 1 \%$ of probability by the F test.

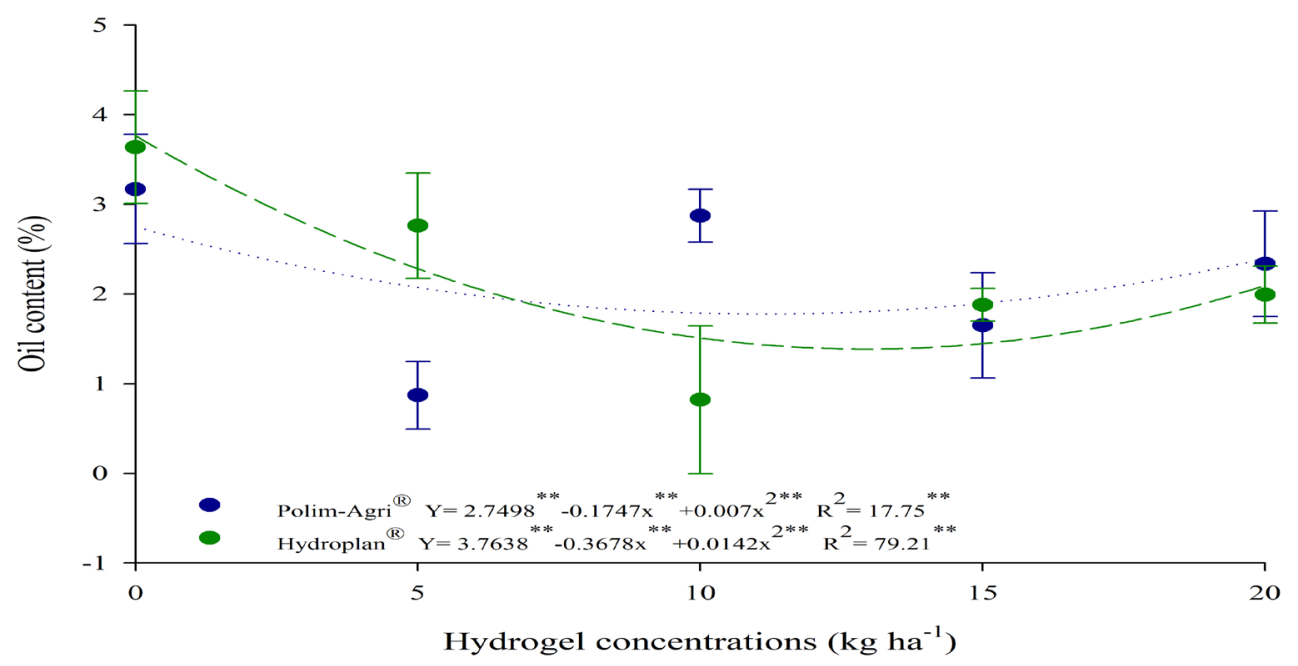

Figure 2. Oil content (\%) in cowpea beans under influence of hydrogel sources and concentrations in the 2015/2016 crop season in Gurupi-TO. 
The water deficit is one of the abiotic stresses that most affect the development of cowpea in the Cerrado, especially when it occurs in periods of pre-flowering, where the average daily demand is higher (mean $=5.4 \mathrm{~mm}$ day $\left.{ }^{1}\right)$ (Bastos et al., 2008), requiring a total of $338.4 \mathrm{~mm}$ throughout its cycle in a conventional system (Murga-Orrillo et al., 2016). In this study, mean daily availability was $4.65 \mathrm{~mm}$ and total of $363 \mathrm{~mm}$, reinforcing that the effects of water limitations are more related to the rainfall distribution than to the total amount of rainfall during the cycle, whose temperatures remained within of the appropriate range from 18 to $34^{\circ} \mathrm{C}$.

In this scenario, cowpea beans accumulated the highest oil content ( $\bar{Y}=3.35 \%)$, although the minimum content observed with the use of hydrogel sources and concentrations applied $(\bar{Y}=1.52 \%)$ in accordance with the values reported in the literature (between $0.5 \%$ and $3.34 \%$ depending on the cultivar), evidencing the low fat content of this legume (Silva et al., 2002; Baptista et al., 2017).
In a study with canola, Moghadam et al. (2011) verified that the higher oil content and the reduced quality of fatty acids in the treatments under water stress and absence of hydroabsorbentpolymerisdependenton thegenotype. However, the application of the polymer under dry condition favored the quality of the oil, due to the decrease in the content of saturated fatty acids and increase of unsaturated, although the yield decreased. According to these authors, under water deficit these effects occur through a shorter growth season; for others, the decrease in oil concentration may be due to the oxidation of some polyunsaturated fatty acids (Singh and Sinha, 2005).

In the composition of cowpea grains, in general, among the main non-essential amino acids are: aspartic acid, glutamic acid and arginine, and essential: leucine and lysine; being the contents of glutamic acid and arginine higher than in common bean (Baptista et al., 2017). In this study, the total soluble amino acid content was influenced only by the hydrogel sources, with the best result $\left(0.38 \mathrm{mg} \mathrm{g}^{-1}\right)$ observed with Polim-Agri PP (Figure 3a).

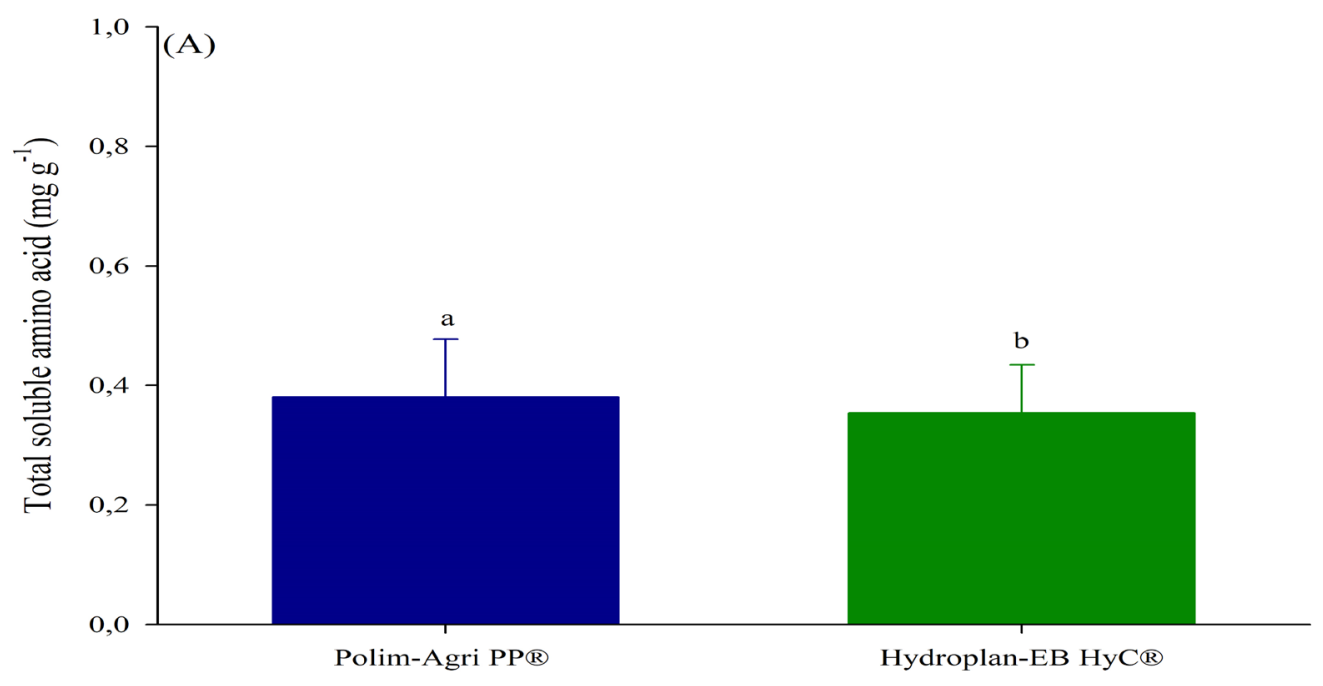

Hydrogel sources 


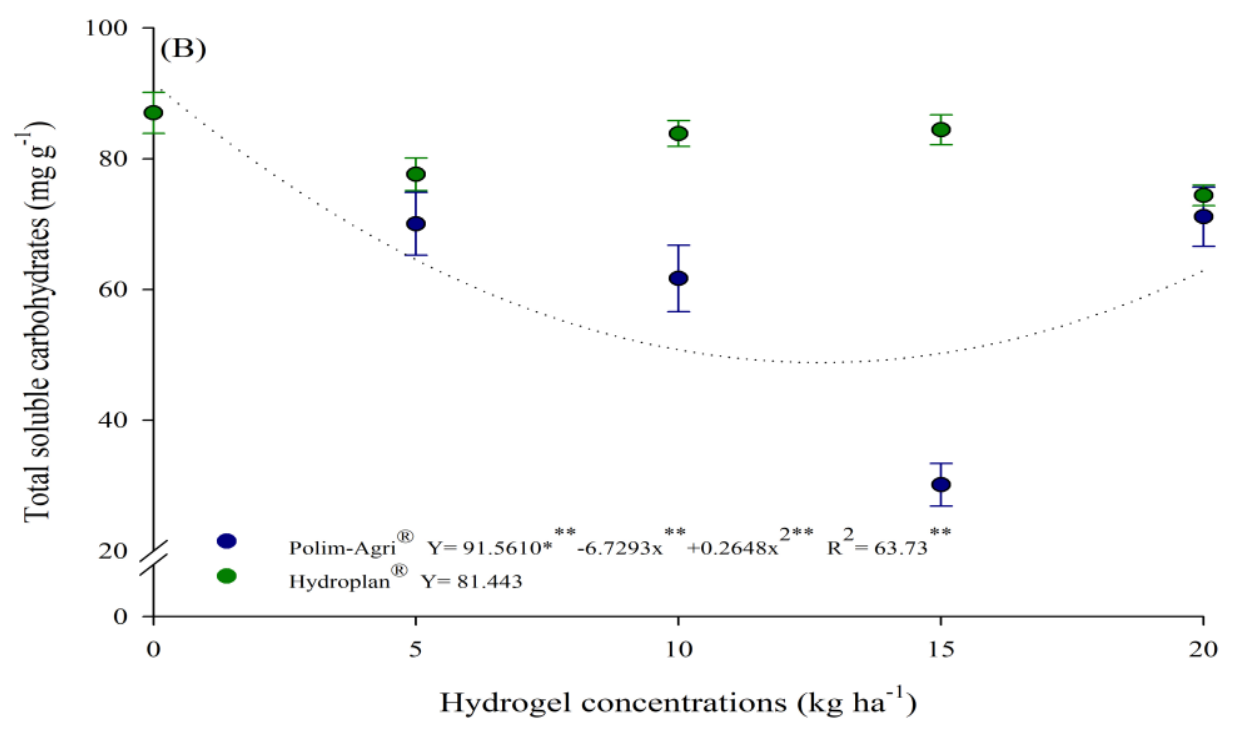

Figure 3. Total soluble amino acids (A) and total soluble carbohydrates (B) in cowpea beans under influence of hydrogel sources and concentrations in the 2015/2016 crop season in Gurupi-TO. Lower case letters differ as sources by the Tukey test at 5\% probability.

Although reports of the effects of hydrogel use on grain amino acid content are rare, in research on cowpea genotypes subject to water stress, Santos et al. (2010) found variations in proline accumulation as a result of the effect of osmotic adjustment involving alteration of enzyme activity and protein synthesis (Taiz and Zeiger, 2013).

On the analysis of the supernatants of the ethanolic extract, the effect of the interaction between the source Polim-Agri PP and the applied concentrations evidenced, in relation to the accumulated in the absence of application (91.56 $\left.\mathrm{mg} \mathrm{g}^{-1}\right)$, a reduction of up to $53.31 \%$ in the total soluble carbohydrates content in the estimated concentration of $12.71 \mathrm{~kg} \mathrm{ha}^{-1}$; however, from that point on the accumulation of carbohydrates of the grains gradually increased to the maximum concentration applied, reaching $62.90 \mathrm{mg} \mathrm{g}^{-1}$ (Figure $3 \mathrm{~b}$ ). Despite the significant effect for the interaction, the use of Hydroplan-EB HyC did not fit any equation model, accumulating, on average, $81.44 \mathrm{mg} \mathrm{g}^{-1}$ of total soluble carbohydrates.
Because of the lack of reference values for total soluble carbohydrate rates in cowpea beans, the term "total carbohydrates" is generally adopted, although there is some doubt about which types are involved. In this sense, the high contents observed in this study contribute to improve the nutritive value of cowpea, being above the carbohydrate levels suggested by Frota et al. (2008) (51.4\%), Cunha et al. (2015) (63.25\%) and Silva et al. (2002) (65.09\%).

Cowpea is a legume rich in protein and starch (Phillips et al., 2003). The analysis of the precipitates of ethanolic extraction verified that the protein content was affected independently by sources and concentrations of hydrogel. The Polim-Agri PP source provided the best protein content of cowpea beans $(243.22 \mathrm{mg}$ $\mathrm{g}^{-1}$ ), slightly higher than that observed with Hydroplan-EB HyC (Figure 4a). Concerning the applied concentrations, the supply of $20 \mathrm{~kg} \mathrm{ha}^{-1}$ of hydrogel promoted gains of up to $15 \%$ in the protein content in relation to the absence of the product (Figure 4b). 

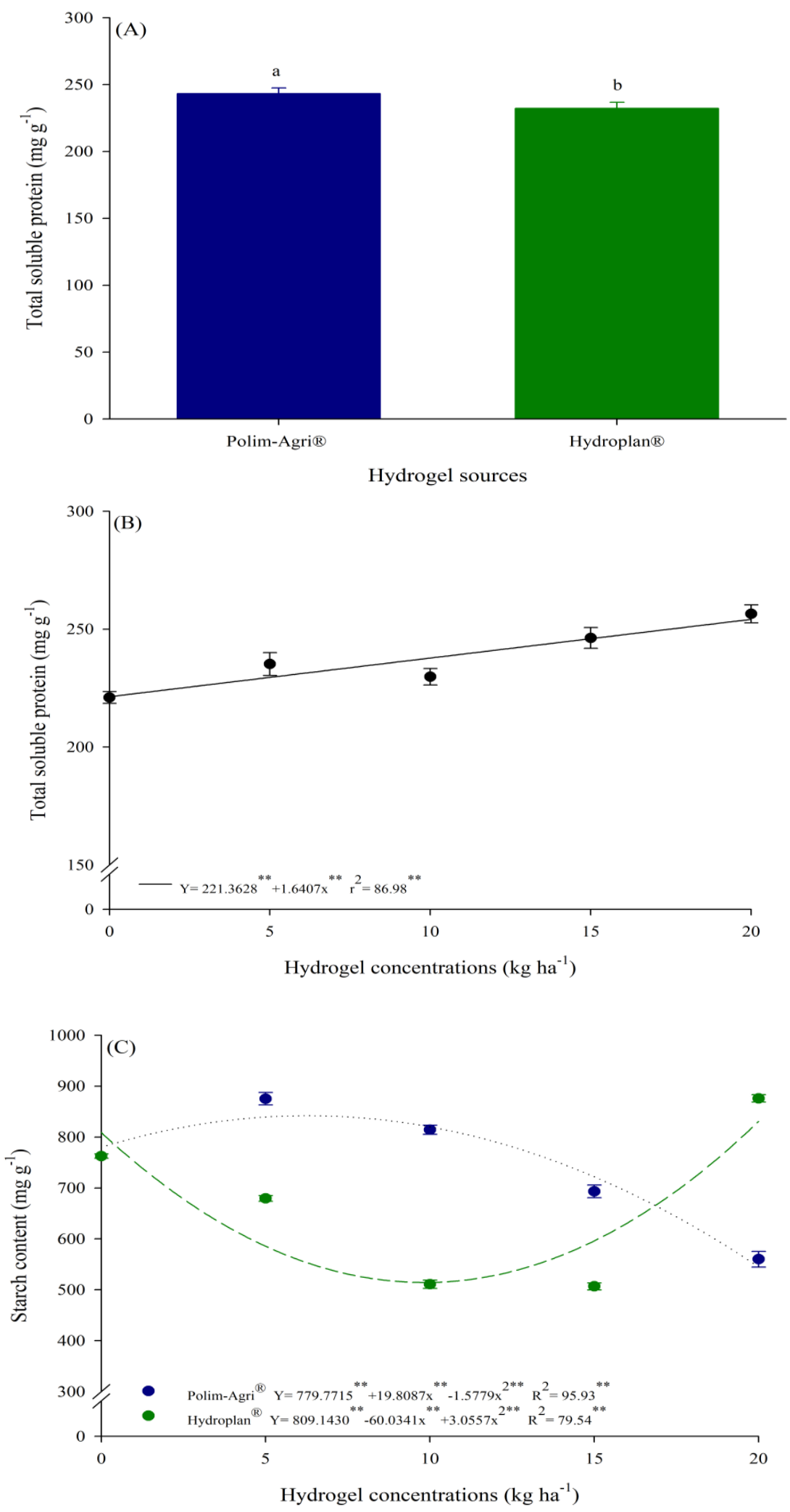

Figure 4. Total protein (A and B) and starch (C) contents in cowpea beans under influence of hydrogel sources and concentrations in the 2015/2016 crop season in Gurupi-T0. Lower case letters differ as sources by the Tukey test at $5 \%$ probability. 
Fidelis et al.- Cowpea beans quality under water-deficit.

Under the conditions of this study, increasing hydrogel concentrations significantly increased the protein content of the grains, with the maximum corresponding to $25.44 \%$, agreeing with the findings of Baptista et al. (2017) and Silva et al. (2017). It is possible to relate this effect to the higher soil water retention promoted by the use of hydrogels, because when there is a limitation in the availability of water in the initial stages of grain development, water stress can result in negative effects on photosynthetic activity, reduction in the production of assimilates for the development of this organ (Pedroso et al., 2009).

In wheat grains, the amount of protein increased when the plants were subjected to water restriction in the aqueous and milky grains phases, as compared to well-watered plants (Beltrano et al., 2006). However, when stress was reversed by rehydration, these authors noticed that the protein content per grain was lower in comparison to stressed plants, but higher than the control (without water restriction). For some authors, the increase of proteins observed in some genotypes after being submitted to water stress, when compared to treatments without stress, can detect a change in the osmotic potential of the cell, to avoid loss of water to the medium (Santos et al., 2010).

Starch is one of the most important forms of carbon reserve in plants and a basic component of world food system (Moreira et al., 2008). In this sense, the negative quadratic behavior observed for Polim-Agri PP showed that the estimated application of $6.28 \mathrm{~kg} \mathrm{ha}^{-1}$ of the hydrogel source had the highest accumulation $\left(842 \mathrm{~g} \mathrm{mg}^{-1}\right.$ ) (Figure 4c), indicating a high water use efficiency in dry soil conditions. The use of Hydroplan-EB HyC gave a positive quadratic response, with a marked reduction of $64 \%$ to the calculated concentration of $9.82 \mathrm{~kg} \mathrm{ha}^{-1}$ in relation to the absence of hydrogel; however, the supply of increasing concentrations promoted discrete gains (up to $21.60 \mathrm{mg} \mathrm{g}^{-1}$ applying $20 \mathrm{~kg}$ $\mathrm{ha}^{-1}$ ), corresponding to the accumulated starch content in the non-application of hydrogel treatment.

In other species subjected to water stress during grain formation, in addition to the decrease in the starch content, changes in the synthesis, composition and physicochemical properties of this carbohydrate occurred, capable of affecting its suitability for different food products (Singh et al., 2008; He et al., 2012).

In cowpea beans, changes in starch morphology influence the quality during cooking, where the gelatinization process occurs (presence of water and high temperatures); although the presence of protein material around the starch is maintained (Moreira et al., 2008). In addition, bioaccessibility studies have shown that the content in raw beans is reduced by up to $15 \%$ after cooking (Cunha et al., 2015) and that the method and cooking time may affect other nutritional characteristics depending on the genotype (Pereira et al., 2014; Pereira et al., 2016).

Based on the analysis of the agronomic variables, which demonstrated that the use of hydrogel attenuates the effects of water deficit and guarantees average productivity of $387 \mathrm{~kg} \mathrm{ha}^{-1}$ (Lopes et al., 2018), the results of this research confirm and improvement in the biochemical quality of cowpea beans cv. BRS Vinagre. However, this influence dependent on the source and the hydrogel concentration, especially the WUE of the low dosis of PolimAgri PP resulting in the best levels of amino acids, proteins and starch of the grains.

In addition to being a good alternative for increasing yield and maintaining crop quality, the use of hydrogel in drier soils contributes 
to greater efficiency in the use of fertilizers (Scremin et al., 2017), assists in reducing toxicity by chemical agents that can cause changes in the soil and groundwater, compromising the environment and human health (Alemzadeh and Vossoughi, 2002); and positively affects the survival rate of plants (Lopes et al., 2010). Through the controlled release mechanism, these super-absorbent polymers modify the physical-chemical properties of the soil, improving the availability of water and reducing losses through percolation and leaching of nutrients, as well as allowing adsorption to remove pesticides from contaminated water, due to their polar groups (Alemzadeh and Vossoughi, 2002; Barbosa et al., 2018).

\section{CONCLUSIONS}

The use of hydrogel improves the biochemical quality of cowpea beans produced under water deficit in southern Tocantins. The use of the Polim-Agri PP hydrogel improves the amino acid and total soluble protein content of cowpea beans. The use of the Hydroplan-EB HyC source improves the total soluble carbohydrate content of the grains. The highest starch contents of the grains are obtained with the application of 6.28 $\mathrm{kg} \mathrm{ha}^{-1}$ of Polim-Agri PP and $20 \mathrm{~kg} \mathrm{ha}^{-1}$ of Hydroplan-EB HyC. These results, together, demonstrate that the use of hydrogel in the cultivation of cowpea in southern Tocantins, a region with severe drought seasons, has great potential for maintaining the quality of grains in this crop.

Conflict of interest: The authors declare that there is no conflict of interest.

\section{BIBLIOGRAPHIC REFERENCES}

Alemzadeh, I.; Vossoughi, M. (2002). Controlled release of paraquat from poly vinyl alcohol hydrogel. Chem. Eng. Process. 41: 707-710.
Alvares, C.A.; Stape, J. L.; Sentelhas, P.C.; Gonçalves, J.L.M.; Sparovek, G. (2013). Köppen's climate classification map for Brazil. Meteorol. Z. 22 (6): 711-728. doi: 10.1127/0941-2948/2013/0507

Baptista, A.; Pinho, 0.; Pinto, E.; Casal, S.; Mota, C.; Ferreira, I.M. (2017). Characterization of protein and fat composition of seeds from common beans (Phaseolus vulgaris L.), cowpea (Vigna Unguiculata L. Walp) and bambara groundnuts (Vigna Subterranea L. Verdc) from Mozambique. J. Food Meas. Charact. 11(2): 442-450. doi: 10.1007/ s11694-016-9412-2

Barbosa, D.H.0; Moura, M.R.; Aouada, F.A. (2018). Hidrogéis nanocompósitos de polissacarídeo com zeólita: avaliação do processo de adsorção do pesticida paraquat. Quim. Nova. 41(4): 380385. doi: 10.21577/0100-4042.20170188

Bastos, E.A.; Ferreira, V.M.; Silva, C.R.; Andrade Júnior, A. (2008). Evapotranspiração e coeficiente de cultivo do feijão-caupi no Vale do Gurguéia, Piauí. Irriga. 13(2): 182-190. doi: 10.15809/ irriga.2008v13n2p182-190

Beltrano, J.; Ronco, M.G.; Arango, M.C. (2006). Soil drying and rewatering applied at three grain developmental stages affect differentially growth and grain protein deposition in wheat (Triticum aestivum L.). Braz. J. Plant Physiol. 18(2): 341350. doi: 10.1590/S1677-04202006000200011

Boughalleb, F.; Abdellaoui, R.; Brahim, N.B.; Neffati, M. (2016). Growth, photosynthesis, water use efficiency and osmoregulation of the wild species Astragalus gombiformis Pomel. Under water deficit. Braz J. Bot. 39: 147-156. doi: 10.1007/ s40415-015-0230-2

Bradford, M.M. (1976). A rapid and sensitive method for the qualification of microgram quantities of protein utilize the principle of protein-dye binding. Anal. Biochem. 72: 248-254. doi: 10.1006/ abio.1976.9999

Castro, R.G. (2016). Desempenho agronômico, qualidade fisiológica e atividade enzimática de sementes de soja sob diferentes doses de glifosato. Recovered from http://repositorio.ufla. br/handle/1/11108 
Fidelis et al.- Cowpea beans quality under water-deficit.

CONAB - Companhia Nacional de Abastecimento. (2019). Levantamento de safra. Recovered from https://www.conab.gov.br/info-agro/safras/ graos

Cunha, E.M.F. (2015). Composição química e atividade antioxidante de linhagens de feijãocaupi (Vigna unguiculata L. Walp.). Recovered from https://repositorio.ufpi.br/xmlui/ handle/123456789/665

Dehkordi, D.K. (2016). The effects of superabsorbent polymers on soils and plants. Pertanika J. Trop. Agric. Sci. 39(3): 267-298.

Dubois, M.; Gilles, K.A.; Hamilton, J.K.; Rebers, P.A.; Smith, F. (1956). Calorimetric method for determination of sugars and related substances. Anal. Chem. 28(3): 350-356. doi: 10.1021/ ac60111a017

Dutra, A.L.F.; Melo, A.S.; Filgueira, L.M.B.; Silva, A.R.F.; Oliveira, I.M.; Brito, M.E.B. (2015). Parâmetros fisiológicos e componentes de produção de feijão-caupi cultivado sob deficiência hídrica. Rev. Bras. Ciênc. Agrár. 10(2): 189-197. doi: 10.5039/ agraria.v10i2a3912

EMBRAPA - Empresa Brasileira de Pesquisa Agropecuária. (2002). Cultivo do feijão-caupi (Vigna unguiculata (L.) Walp. Teresina: Embrapa Meio-Norte. 108p.

Ferreira, D.F. (2011). SISVAR: a computer statistical analysis system. Ciênc. Agrotec. 35 (6): 10391042.doi: 10.1590/S1413-70542011000600001

Fidelis, R.R.; Lopes, M.B.S.; Martinez, R.A.S.; Marques, K.R.; Aguiar, R.W.S.; Veloso, D.A. (2018). Influence of hydrogel use on soybean cultivation hydrical stress. Biosci.J.34(5): 1219-1224. doi: 10.14393/ BJ-v34n5a2018-39470

Freitas, R.M.O.; Dombroski, J.L.D.; Freitas, F.C.L.; Nogueira, M.W.; Pinto, J.R.S. (2017). Physiological responses of cowpea under water stress and rewatering in no-tillage and conventional tillage systems. Rev. Caatinga. 30(3): 559-567. doi: $10.1590 / 1983-21252017 \mathrm{v} 30 \mathrm{n} 303 \mathrm{rc}$
Friedman, M.; Brandon, D.L. (2001). Nutritional and health benefits of soy proteins. J. Agric. Food Chem. 49 (3): 1069-1086. doi: 10.1021/jf0009246

Frota, K.M.G.; Soares, R.A.M.; Arêas, J.A.G. (2008). Composição química do feijão caupi (Vigna unguiculata L. Walp), cultivar BRS-Milênio. Food Sci. Technol. 28(2): 470-476. doi: 10.1590/ S0101-20612008000200031

Guilherme, M.R.; Aouada, F.A.; Fajardo, A.R.; Martins, A.F.; Paulino, A.T.; Davi, M.F.T.; Rubira, A.F.; Muniz, E.C. (2015). Superabsorbent hydrogels based on polysaccharides for application in agriculture as soil conditioner and nutrient carrier: A review. Eur. Polym. J. 72: 65-385. doi: 10.1016/j. eurpolymj.2015.04.017

He, J.F.; Goyal, R.; Laroche, A.; Zhao, M.L.; Lu, Z.X. (2012). Water stress during grain development affects starch synthesis, composition and physicochemical properties in triticale. J. Cereal Sci. 56(3): 552-560. doi: 10.1016/j. jcs.2012.07.011

INMET - Instituto Nacional de Meteorologia. (2016). Dados climatológicos. Recovered from http://www.inmet.gov.br/portal/index. php?r=estacoes/estacoesAutomaticas.

Khalaki, M.A.; Ghorbani, A.; Ouri, A.E.; Shokouhian, A.A.; Jafari, A.A. (2019). Varying the vegetative and morphological traits of Thymus kotschyanus L. submitted to potassium silicate nanoparticles, superabsorbent hydrogel, effective microorganisms and animal manure. Biosci. J. 35 (2): 115-125. doi: 0.14393/BJv35n1a2019-41832

Lopes, J.L.W.; Silva, M.R.; Saad, J.C.C.; Angélico, T.S. (2010). Uso de hidrogel na sobrevivência de mudas de Eucalyptus urograndis produzidas com diferentes substratos e manejos hídricos. Cienc. Florestal. 20(2): 217-224. doi: $10.5902 / 198050981847$

Lopes, M.B.S.; Barros, H.B.; Chagas Junior, A.F; Santos, M.M.; Silva, N.C.; Fidelis, R.R. (2018). Water-retaining polymer as a soil conditioner in cowpea under water stress. Comun. Sci. 9(4): 680-686. doi: 10.14295/cs.v9i4.2709 
Macrae, J.C.; Smith, D.; McCready, R.M. (1974). Starch estimation in leaf tissue - A comparison of results using six methods. J. Sci. Food Agric. 25 (12): 1465-1469. doi: 10.1002/jsfa.2740251206

Mamann, A.T.W.; Silva, J.A.G.; Scremin, O.B.; Manatai, R.D.; Scremin, A.H.; Dornelles, E.F. (2017). Nitrogen efficiency in wheat yield through the biopolymer hydrogel. Rev. Bras. Eng. Agr. Amb. 21(10): 697-702. doi: 10.1590/1807-1929/ agriambi.v21n10p697-702

Melo, F.B.; Bastos, E.A.; Cardoso, M.J.; Ribeiro, V.Q. (2018). Cowpea response to phosphorus and zinc. Rev. Caatinga. 31 (1): 240-245. doi: 10.1590/1983-21252018v31n128rc

Moghadam, H.R.T.; Zahedi, H.; Ghooshchi, F. (2011). Oil quality of canola cultivars in response to water stress and super absorbent polymer application. Pesqui. Agropecu. Trop. 41(4): 579-586. doi: 10.5216/pat.v41i4.13366

Moreira, P.X.; Barbosa, M.M.; Gallão, M.I.; Lima, A.C.; Azeredo, H.M.C.; Brito, E.S. (2008). Estrutura e Composição Química do Feijão-Caupi (Vigna unguiculata (L.) Walp). In: Brito, E.S. (ed.) Feijão-caupi. pp. 13-24. Forataeza: Embrapa Agroindútria Tropical. 97p.

Murga-Orrillo, H.; Araújo, W. F.; Rocha, P.R.R.; Sakazaki, R.T.; Dionisio, L.F.S.; Polo-Vargas, A.R. (2016). Evapotranspiração e coeficiente de cultivo do feijão-caupi cultivado em solo do cerrado submetido à cobertura morta. Irriga. 21(1): 172187. doi: 10.15809/irriga.2016v21n1p172-187

Pedroso, T.Q.; Scalco, M.S.; Carvalho, M.L.M.; Resende, C.A.; Otoni, R.R. (2009). Qualidade de sementes de cafeeiro produzidas em diferentes densidades de plantio e regimes hídricos. Coffee Sci. 4 (2): 155-164.

Peoples, M.B.; Faizah, A.W.; Rerkasem, B.; Herridge, D.F. (1989). Methods for evaluating nitrogen by nodulated legumes in the field. Australian Centre for International Agricultural Research, CANBERRA: Austrália. 76p.

Pereira, E.J.; Carvalho, L.M.J.; Dellamora-Ortiz, G.M.; Cardoso, F.S.N.; Carvalho, J.L.V. (2016). Effect of different home-cooking methods on the bioaccessibility of zinc and iron in conventionally bred cowpea (Vigna unguiculata L. Walp) consumed in Brazil. Food Nutr. Res. 60(1): e29082. doi: 10.3402/fnr.v60.29082

Pereira, E.J.; Carvalho, L.M.J.; Dellamora-Ortiz, G.M.; Cardoso, F.S.N.; Carvalho, J.L.V.; Viana, D.S.; Freitas, S.C.; Rocha, M.M. (2014). Effects of cooking methods on the iron and zinc contents in cowpea (Vigna unguiculata) to combat nutritional deficiencies in Brazil. Food Nutr. Res. 58(1): e20694. doi: 10.3402/fnr.v58.20694

Pereira, J.S.; Olszevski, N.; Silva, J.C. (2018). Retenção de água e desenvolvimento do feijão caupi em função do uso de polímero hidrorretentor no solo. Reveng. 26(6): 582-591. https//doi. org/10.3402/fnr.v60.29082.

Phillips, R.D.; McWatters, K.H.; Chinnan, M.S.; Hung, Y-C.; Beuchat, L.R; Sefa-Dedeh, S.; Sakyi-Dawson, E.; Ngoddy, P.; Nnanyelugo, D.; Enwere, J.; Komey, N.S.; Liu, K; Mensa-Wilmot, Y.; Nnanna, I.A.; Okeke, C.; Prinyawiwatkul, W.; Saalia, F.K. (2003). Utilization of cowpeas human food. Field Crops Res. 82(2-3): 193-213. doi: 10.1016/S03784290(03)00038-8

Santos, C.F.; Lima, G.P.P.; Morgado, L.B. (2010). Tolerância e caracterização bioquímica em feijão-caupi submetido a estresse hídrico na préfloração. Naturalia. 33: 34-44.

Santos, H.G.; Jacomine, P.K.T.; Anjos, L.H.C.; Oliveira, V.A.; Lumbreras, J.F.; Coelho, M.R.; Almeida, J.A.; Cunha, T.J.F.; Oliveira, J.B. (2013). Sistema brasileiro de classificação de solos. $3^{\text {th }}$ ed. EMBRAPA: Brasília. 353p.

Sartore, L.; Vox, G.; Schettini, E. (2013). Preparation and performance of novel biodegradable polymeric materials based on hydrolyzed proteins for agricultural application. J. Polym. Environ. 21(3): 718-725. doi: 10.1007/s10924013-0574-2.

Scremin, O. B.; Silva, J.A.G.; Mamann, A.T.W.; Mantai, R.D.; Brezolin, A.P.; Marolli, A. (2017). Nitrogen efficiency in oat yield through the biopolymer hydrogel. Rev. Bras. Eng. Agrí. Ambient. 21(10): 379-385. doi: 10.1590/1807-1929/agriambi. v21n6p379-385 
Silva, D.O.M.; Santos, C.A.F.; Seido, S.L.; Coleho, W.C.P.; Aquino, D.A.L. (2017). Retention of proteins and minerals after cooking in cowpea genotypes. Pesqui. Agropecu. Trop. 47(3): 353-359. doi: 10.1590/1983-40632016v4747261

Silva, S.M.S.; Maia, J.M.; Araújo, Z.B.; Freire Filho, F.R. (2002). Composição Química de 45 Genótipos de Feijão-Caupi (Vigna unguiculata (L.) Walp). Comunicado Técnico 149. Tereseina: EMBRAPA.

Singh, S.; Singh, G.; Singh, P.; Singh, N. (2008). Effect of water stress at different stages of grain development on the characteristics of starch and protein of different wheat varieties. Food Chem. 108(1): 130-139. doi: 10.1016/j. foodchem.2007.10.054

Singh, S.; Sinha, S. (2005). Accumulation of metals and its effects in Brassica juncea (L.) Czern. (cv. Rohini) grown on various amendments of tannery waste. Ecotoxicol. Environ. Saf. 62(1): 118-127. doi: 10.1016/j.ecoenv.2004.12.026

Sousa, M.B.; Damasceno-Silva, K.J.; Rocha, M.M.; Menezes Júnior, J.A.N.; Lima, L.R.L. (2017). Adaptability and yield stability of cowpea elite lines of semi-prostrate growth habit in the cerrado biome. Rev. Ciênc. Agron. 48 (5 - Especial): 832-839. doi: 10.5935/1806-6690.20170098

SSI - SYSTAT SOFTWARE Inc. (2006). Systat Software Inc, Sigmaplot for Windows, version 10. Recovered from http://www.systat.com/ products/sigmaplot/

Taiz, L.; Zeiger, E. (2013). Fisiologia vegetal. $5^{\text {th }}$ ed. Porto Alegre, Brazil: Artme. 918p.

Ullah, F.; Othman, M.B.H.; Javed, F.; Ahmad, Z.; Akil, H.M.D. (2015). Classification, processing and application of hydrogels: A review. Mat. Sci. Eng. C. 57: 414-433. doi: 10.1016/j.msec.2015.07.053 